\title{
Family-based Policy in the Period of Low Fertility Rate
}

\author{
Wang Yan \\ JI Lin Agriculture University \\ Chang Chun, China \\ yirenhaomeng@163.com
}

\begin{abstract}
The aim of this study was to demonstrate the relationship between the numbers of children in family and family benefits; and determine whether there was a positive correlation. This paper used historical analysis method, to compare fertility rate and family welfare policy in different historical periods. The experience showed that China has had a high fertility period in history, when the public resources divided equally by country. Developed countries' experience also showed that the concern for family including offering subsidy or service was helpful to improve fertility. These examples illustrated that when the state undertook supporting functions on family, with the non-exclusive and equal distribute in public resources, people tend to bearing more babies. It is necessary to establish a familybased social policy to help families raising babies, thus people may love to bear more babies.
\end{abstract}

Keywords-low fertility rate; distribution model; family-based policy; work-family balance

\section{INTRODUCTION}

Some developed countries' developmental experiences tell us that the level of economic development is inversely proportional to the fertility rate. In recent 30 years, China's economy has developed rapidly; but the fertility rate has dropped rapidly also. The low fertility rate has triggered many problems, such as population aging, labor supply insufficient, and irrational population structure. In order to solve them, the state relaxed its more than three-decade-old family planning policy, and implemented the universal two-child policy. Suddenly for a moment, when people ran into each other, most probably be ask:"do you want another baby?" In fact, to have a baby is not only a decision in family, but also an important thing for a country. For some countries with fewer natural resources, too many people is a burden, so they try their best to develop, which is "the best birth control pills", the true saying many scholars believed. For some countries, too little population is also a problem. China now is facing this situation, with aging population and low fertility. Why do people control the number of children voluntarily? Some scholars believe in it varies between different families, but the main paradigm explaining fertility will and fertility behavior is economy. Becker and Leeibenstein used the frame of hypothesis of economic man, cost-benefit analysis, incomeprice elasticity to analyze families' preference for the number and quality of children. If people do not have more babies because of economic pressure, it means that the state may have to encourage them by offering some benefits or services..

\section{WELFARE POLICY AND FAMILY FERTILITY DECISION IN CHINA}

Since the reform and opening policy implemented, the traditional social welfare system and resource allocation has changed, from the egalitarian distribution to socialized distribution. This completely changed the basic way of life, including employment, marriage, birth, medical treatment, pension and other aspects of life.

\section{A. Family fertility decision-making under the egalitarian distribution model}

Before the reform and opening up, China implemented a planned economy and public ownership. The most important feature of the welfare system is the principle of egalitarianism. In city, if you have permanent urban residence, you will get not only a job, when you old enough to work, but also all kind of welfare, including wages, holiday benefits, medical care, pension, baby-caring, and even a house. So it does not affect people's enthusiasm of bearing with a high rate of employment at that time. In rural areas, the resource ownership is the collective ownership with the production team as the main body. In this period, the main source of income, such as rations, vegetables, firewood, private plots, etc., are allocated by the number of family members, which means the more family members you have, it more resources you will get. Children bring about significant economic benefits to family, because they eat less, but can get more from the country, and can do certain work as a helper in "production team". So for rural residents, there is no pressure at all to raise children. In the opinion of Zheng Weidong, collectivization did not improve the economic level of Chinese farmers, but lead to a high fertility rate, because the collective born the cost of raising child, rather than the family [1]

\section{B. Family fertility decision-making under the influence of competition model}

When there is no exclusive public resource in the social space, families' rationality leads to bear more children. When the social resources cannot bear such large scale of population, there must be some appropriate institutional arrangements to suppress the negative externalities produced by the family 
rational behavior. There is a paradox between family rationality and social rationality. In turn, when the resources in the community have a certain system of restriction, people need to work hard to get it; thus, people will tend to bear fewer children. That is to say, the more abstract of the resources existed in the public domain, the more inclined to allocate the individual's ability, people tend to bear fewer children [2]. If a society's population is too small or the fertility rate is too low, affecting the human's own replacement and population structure imbalance, and the families are reluctant to carry out child on account of their own rationality, so it becomes the situation that public goods supplied by private. With the transition of economic system and national economic development and transformation, the public goods are no longer allocated with no restriction, which means you need to earn it by yourself, what you earned equals you devoted. The reform of housing, health care, and education raised people's living cost. Combined with the external family planning policy, people's fertility desire and fertility level are gradually going down. Far fewer couples than expected have applied for permission to have a second child, a year after government announced the relaxation of its one-child policy to encourage births. It may indicate that the motivations that trigger fertility behavior are not strong, and strong support are lack of in the process of raising children. Therefore, the construction of family social policies should be promoted in a timely manner, and family-based support for child births should be supported

\section{THE INTRODUCTION OF FAMILY PERSPECTIVE IN SOCIAL} POLICY

\section{A. Experiences of family policy in developed countries}

The family is the earliest economic and social organization in man's history, and is the most microscopic environment of material and spiritual life, but it reflects the changes in social life rapidly and sensitively. The government intervenes private life has a long history in European countries, for family problems are seen as the result of anomie or deviant behavior, and it must been controlled and regulated. As early as the 19th century, a series of laws and service procedures (such as social work) and welfare institutions were developed to regulate and dispose of children and adolescents such as deviant or crime. This set of practices was called "family policy". In the twentieth century, social policies to promote family development began to develop; France and Sweden developed a "family policy". Since then, many countries have adopted family allowances or child benefits as a basic policy tool for responding to population changes. After the Second World War, almost most countries in Europe have introduced a subsidy policy, 50 years known as the "golden age" of the development of family allowances [3]. After the 1960s, the development of economy and society makes people's life concept and lifestyle changing significantly, the first marriage age postponed, the marriage stability weakened, families changing to miniaturization, core and diversified direction[4]. After the 1970s and 1980s, in order to cope with the changes in family patterns, raising fertility rate and promoting economic growth, family-related policies gradually entered the modernization phase, including extensive provision of cash items, materials or services and time projects. Since the 1990s, the welfare countries of Europe have developed policies to promote the balance of family and work. The main strategies are involved in holiday project, child care system, and the employment of women. Wu Fan analyzed the debt crisis and demographic structure of the Europe, finding that the Nordic region (except Iceland) know as the welfare model can survive in the crisis for two reasons. One is the "system bonus" brought about by the welfare reform of human capital investment in the 1990s, and the other is the higher fertility rate compared with other European countries. Higher fertility rates are inseparable from the stable economic income, gender equality, and policies encouraging fertility. Family policies include a range of policy arrangements, such as maternity benefits, paid maternity leave and parental leave, as well as child benefits, which significantly reduce the money, time and psychological costs of parenting [5]. In such countries, especially OECD countries spend a lot on family benefits. Detail figures can be seen in fig1[6]. Family policy, population structure and economic development have formed a virtuous circle and mutual promotion in there.

\section{B. Orientation of China's family policy}

Unlike the West, the family in China is not just an economic unit, but also carries more emotional and traditional heritage. According to their own needs, the state put the family in different roles, not just a private domain. Since ancient times we have the idea of the clan and the country sharing the same structure. The country and families are in the same boat, so the families should sacrifice themselves for country's interest. In return, the state provides social welfare through city's units and rural collective, which means the family bearing little welfare. With the decline of unit system and rural collective economic system, the government gradually withdraws the responsibility of national welfare and emphasizes family and personal's responsibility. However, the developments of the family run counter to the country's desire. The stable low fertility level, rapid population aging, largescale population migration and rising urbanization level are all impacting on each Chinese family. In modern times, Chinese families are having few kids or only on kid, which happening in the background of population changing and social transformation. Population migration caused family members segregation, which weakens the supply and security capacity of families' welfare supply. China does not have a clear family social policy framework currently, most related to the establishment of the family policy, such as marriage, adoption, family membership with the move, and the maintain obligation. The real sense of family policy is also focused on problem families and the loss of family-dependent marginal groups, such as subsistence allowances and housing security policies, lacking the support for ordinary families. Even if there are marriage, maternity, child care, pension and other policy matters, but they are belong to different government departments, showing the feature of decentralized and fragmented[7]. At present, the Ministry of Family Planning has set up a family development department, indicating that the government level began to focus on the development of family capacity. Especially in the development of minority aging, the state should pay more attention to the important role 
of family policy to build a protection and support the family policy environment.

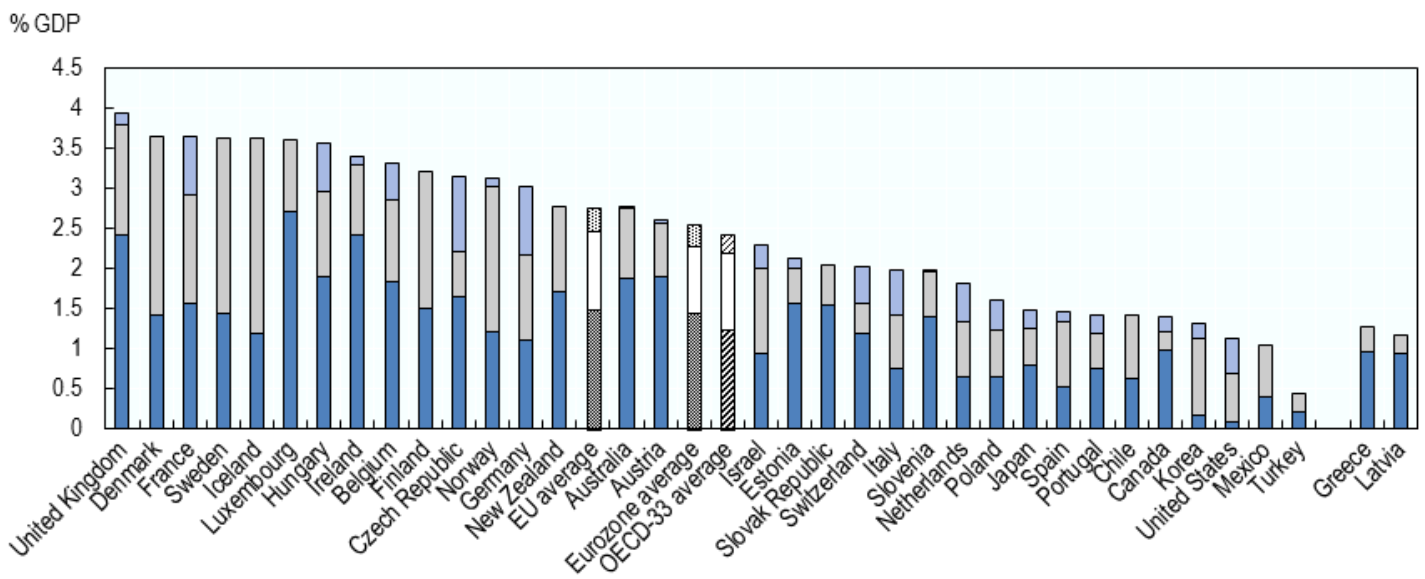

Fig 1. Public spending on family benefits

Public expenditure on family benefits by type of expenditure, in per cent of GDP, 2013 and latest available

TABLE I. PUBLIC SPENDING ON FAMILY BENEFITS

PUBLIC EXPENDITURE ON FAMILY BENEFITS BY TYPE OF EXPENDITURE, IN PER CENT OF GDP, 2013 AND LATEST AVAILABLE ${ }^{\mathrm{A}}$

\begin{tabular}{|l|c|c|c|c|}
\hline & Total & Cash & Services & $\begin{array}{c}\text { Tax-breaks for } \\
\text { families }\end{array}$ \\
\hline United Kingdom & 3.95 & 2.42 & 1.38 & 0.15 \\
\hline Denmark & 3.66 & 1.42 & 2.24 & 0.00 \\
\hline France & 3.65 & 1.56 & 1.35 & 0.74 \\
\hline Sweden & 3.64 & 1.45 & 2.19 & 0.00 \\
\hline Iceland & 3.63 & 1.20 & 2.43 & 0.00 \\
\hline Luxembourg & 3.61 & 2.72 & 0.89 & 0.00 \\
\hline Hungary & 3.57 & 1.91 & 1.05 & 0.62 \\
\hline Ireland & 3.40 & 2.43 & 0.87 & 0.11 \\
\hline Belgium & 3.33 & 1.83 & 1.03 & 0.47 \\
\hline Finland & 3.21 & 1.51 & 1.70 & 0.00 \\
\hline Czech Republic & 3.14 & 1.65 & 0.57 & 0.93 \\
\hline Norway & 3.13 & 1.20 & 1.82 & 0.11 \\
\hline Germany & 3.03 & 1.10 & 1.07 & 0.86 \\
\hline New Zealand & 2.76 & 1.71 & 1.05 & 0.00 \\
\hline EU average & 2.76 & 1.49 & 0.98 & 0.29 \\
\hline Australia & 2.75 & 1.87 & 0.87 & 0.01 \\
\hline Austria & 2.61 & 1.90 & 0.67 & 0.04 \\
\hline $\begin{array}{l}\text { Eurozone } \\
\text { average }\end{array}$ & 2.55 & 1.45 & 0.83 & 0.27 \\
\hline $\begin{array}{l}\text { OECD-33 } \\
\text { average }\end{array}$ & 2.43 & 1.25 & 0.94 & 0.23 \\
\hline Greece &.. & 0.97 & 0.31 &.. \\
\hline Latvia &.. & 0.93 & 0.24 &.. \\
\hline
\end{tabular}




\section{THE CONSTRUCTION OF FAMILY-BASED POLICY IN LOW FERTILITY PERIOD}

At present, economic factors affect people's fertility desire and then the low fertility rate is related to the realization of family function. Shi Zhi lei, Yang Yunyan took a large sample survey on the desire about second child, showing that more than half of the families' unwilling due to economic pressure [8]. The provision of universal funds and services to the family helps to alleviate the low fertility crisis, enhance the ability of families to withstand risks and the sustainable development of society. Family policy mainly refers to the government's policy of stabilizing the family and taking on the family function, mainly through the system, the project, the service and so on to influence the family function and welfare policy.

\section{A. Work-family balance policy}

With the development of society and the awareness of gender equality, Chinese women's education level, employment rate and social participation are significantly improved. Because of their particularity, women cannot avoid the conflict between fertility, employment and their family roles. Song Jian and Zhou Yu-xiang using the 2010 third survey data of Chinese women's social status concluded that bearing two children will significantly reduce the possibility of urban women's employment, both urban and rural areas. Fertility interruption will significantly reduce women's employment possibility[9]. The contradictions between the continuing employment and the fertility are naturally occurring in modern society, and there is no difference between urban and rural areas. Society requires women to fulfill their job responsibilities and take care of the family. Women who are the main contributors to the family are under great pressure. If there is no friendly family policies support, fertility is punitive for women. Balancing the work and the family is not only personal and family's affair, but also the responsibility of the government and the employment organization. Under the influence of rational preferences, women's employment is already faced with great discrimination and women's maternity benefits are infringed in varying degrees. If there is no more effective support policy, fertility behavior is also blocked, even if the "comprehensive two" policy is difficult to reverse the problem of low birth rate. The friendly family policy model includes some core projects, such as labor market resilience, child care services coverage, paid parental leave and total expenditure on family policy. These projects have effectively improved the living and working environment of women, which is conducive to women free access to the labor market without worries, but also make children bathed in maternal love and healthy growth.

\section{B. Allowance and care support policy}

In addition to economic factors mentioned above, children's care is also a common problem. When the small tendency of family size is common, children cannon grow up looked after by brothers or sisters, more often by the elders, triggering a series of problems, generation-skipping education, left-behind children. China has no early policy on the development of children, lacking special care for early childhood. The family is the most important place for children to grow, and it is also the most important person for children to grow. But when the family's tending has difficulties, the government should give universal attention to the children who are the future of the motherland and the country. However, under the family-based traditional culture, children are regarded as the private property of the family in our country; the government's role is marginal and residual. The government only undertakes the welfare responsibility of special children such as orphans and sickness for a long time. 2010 was praised as the first year of Chinese children's welfare, for "Opinions on Strengthening the Work of Orphans Protection" is considered to be the first attempt by the Government to establish a modest universal child care system. Relevant policies issued subsequently, such as the classification of child assistance system pilot, the rural school nutrition improvement program and so on; show that the scope of child welfare policy is expanding [10]. But in general, our children's policy is subsidiary and marginal, with limited project, limited coverage, and limited financial expenditure. In March 2016, the National Health Commission decided to conduct a survey on the demand for child care services in 10 cities across the country, to understand the willingness of bearing, child-rearing, and the demand for services, indicating that universal child welfare is coming. The number of children and the education are related to the quality and structure of the country's labor force and are of vital importance to the future socio-economic development of a country or region. Our country should also incorporate universal child allowance and care into the social policy system and establish a childcentered family policy.

\section{V.CONCLUSIONS}

The family has been regarded as the basic legal units for rearing children in the modern society, and many functions of the family have been lost and transferred, in which the family's reproductive function is gradually shrinking. In today's world, many countries are from reproductive worship phrase to high fertility and then to reproductive revolution, fertility dropping to the level of replacement or falling down continually. According to the sixth census, the third survey of women's social status and other national and local surveys, data show that fertility in some areas of our country has fallen below the replacement level. The traditional culture of the more decedents the happier has been quietly changing in the implementation of social development and family planning policies. The meaning of child for the family is no longer economic but emotional. One cannot get more from rearing but devote more economy and energy. Children are the future and hope of a country, related to the long-term development of a nation country. Families are the cornerstone of society. They play a central economic role, are a crucial engine of solidarity, and provide protection and insurance against hardship. Families offer identity, love, care and development to their members and form the core of many social networks. Learned from the welfare countries' policy aiming to promote economy development and improve fertility rate, the government should help family rear child, offer some allowance and service, and establish a series of social policy 
with family as a unit, which is a general trend and beneficial for future generations.

\section{REFERENCES}

[1] Zheng Weidong. From " fortune flow to family economic support": A New View on the Causes of High Birth Rate of Rural Population in Collectivization Period - A Case Study of Dongcun in Shandong Province (1949-1973), Huxiang Rural Forum, 2008 issue.

[2] Wang Shuixiong. Game Model of Fertility: China's example, vol.6, 2002 in Chinese.

[3] Wang Yang. Foreign experience and China's reference of social policy based on family perspective, Shanghai Urban Management,vol.6,2015 in Chinese.

[4] Wu Fan. China's Family Changes and Policy Reflections under the Background of the Second Population Change, Guangdong Social Sciences, vol.2,2012 in Chinese
[5] Wu Fan. Social Observations of European Debt Crisis Based on Population Perspective - Warning and Enlightenment to China, Population Research,vol.5, 2013,in Chinese.

[6] OECD database. http://www.oecdchina.org/

[7] Hu Zhan, Peng Xizhe. Family Policy in China under the Background of Family Change, Population Research, vol.3, 2012, in Chinese.

[8] Shi Zhilei, Yang Yunyan. Research on the Fertility Desire and Behavior of Selective-two Child Family, Population Research, vol.5, 2014, in Chinese.

[9] Song Jian, Zhou Yuxiang. Chinese married women's fertility state's impact on employment - concurrently on the mediation role of economic support and care support, Women's Studies, vol.7, 2015, in Chinese.

[10] Liu Jitong. Characteristics Framework of Children's Welfare with Chinese Characteristics and Framework of Children's Welfare System, Journal of Humanities, vol.5,2012, in Chinese. 